\title{
The Relationship Between Capital Structure and Financial Performance of Firms in Ghana and Nigeria
}

\author{
K. Opoku-Asante, E. C. Winful, M. Sharifzadeh, and M. Neubert
}

\section{ABSTRACT}

This study aimed to investigate, using a sectorial analysis, the relationship between capital structure and financial performance and consider the effect of debt maturity on the relationship. the relationship between capital structure and financial performance, considering the debt maturity, using 425 cross-sectional firm-year samples from firms in Ghana and Nigeria from 2014 to 2019. The empirical findings suggested a significant negative relationship between capital structure and financial performance. Debt maturity did not affect the relationship between capital structure and financial performance. However, the Industry influences the direction of the relationship between capital structure and financial performance. Also, debt maturity influences the capital structure performance relationship in specific sectors but not the market. This paper extends on previous studies on the relationship between capital structure and financial performance by incorporating sectorial and debt maturity on firms in Ghana and Nigeria. The findings of this study will assist finance managers in maximizing performance by considering financially sensible heterogeneities such as the sector and the funding source when making financing decisions.

Keywords: Capital Structure, Debt Structure, Debt Maturity, Financial Performance, Financial Structure.

\section{INTRODUCTION}

One of the most vital issues in corporate finance is deciding on the means of financing the operation of the business. Businesses funding sources can be either internal or external. The mix of internal and external sources of funding is critical to the success or failure of the business. Brigham and Gapenski (1996) described this decision as important and can affect the firm's ability to compete effectively in its environment. If a firm relies solely on equity capital and internal funding, it may face challenges in expanding and taking advantage of opportunities in the market. Businesses, therefore, may take on debt capital to expand and increase the earning potential of these firms.

The financing decision's effect on firm profitability has been described as the most perplexing. The introduction of debt capital leads to agency costs between the managers and shareholders and between managers and debt holders Jensen and Meckling (1976). Equity holders are much more interested in their business's capital structure as more debt can have detrimental consequences on the return on equity. Increasing debt capital may lead to higher operational risk and a higher interest ratio. Capital structure decisions should be made with an understanding of the risk-return relationship about debts. Empirical studies have resulted in mixed results of the relationship between capital structure and financial
Submitted : January 26, 2022

Published : February 16, 2022

ISSN: 2507-1076

DOI: $10.24018 /$ ejbmr.2022.7.1.1282

\section{K. Opoku-Asante*}

Accounting And Finance Department, Accra Technical University, Accra, Ghana.

(e-mail: kopoku-asanteus ${ }^{\circledR}$ atu.edu.gh)

E. C. Winful

Accounting And Finance Department, Accra Technical University, Accra, Ghana.

(e-mail: ewinful@atu.edu.gh)

M. Sharifzadeh

School of Management, Walden University, Minneapolis, USA.

(e-mail:

mohammad.sharifzadeh ${ }^{\circledR}$ mail.waldenu.edu) M. Neubert

School of Management, Walden University, Minneapolis, USA.

(e-mail: Michael.neubert ${ }^{\circledR}$ mail.waldenu.edu)

*Corresponding Author performance. These studies have resulted in a mix of both positive and negative relationships between capital structure and financial performance.

Empirical studies of the capital structure and performance relationship have resulted in an ongoing unanswered question about whether capital structure positively or negatively influences the financial performance of firms. Gallegos Mardones and Ruiz Cuneo (2020) found an inconsistent relationship between financial performance and the elements of capital structure among Latin American companies. They also found mixed results for different countries and companies. As company performance is critical to the economy in general, and in specific, shareholders and investors, it is critical to have a fuller appreciation of all the factors that influence financial performance.

Few studies have investigated the relationship between capital structure and financial performance in developing economies with less developed financial and social infrastructure. Abor (2005) lamented that the theories of capital structure proposed in finance literature are inadequate in determining an optimal capital structure in practice, not to speak of that in developing economies. Benmelech and Dvir (2013) pointed out the considerable attention that debt maturity is gaining in finance literature. Appreciation of the effect of debt maturity on the relationship between financial performance and capital structure on a sectorial basis is relevant, especially for firms operating in developing 
economies such as those in West Africa. As Afza and Hussain (2011) argued, pooling all firms from various industries to determine the capital structure and financial performance relationship, without considering the maturity of debt and industry specifics, may be straightforward but neglects the financially sensible heterogeneities. This study adopts a sectorial-specific analysis for the relationship between capital structure and financial performance. Also, the study adopted proportionate analyses of total leverage that enabled the effect of the timing of debt repayment on the financial performance for each sector to be considered in the analysis. The object was to identify any discrepancy between the debt maturity on financial performance that managers, policymakers, and investors should be aware of when making financing decisions. To the authors' knowledge, no other study on the relationship between capital structure and financial performance in West African countries has been conducted to include the relationship on industrial bases and debt maturity bases. This study contributes to existing literature and fulfills the research gap. Specifically, the study looked at firms operating in Ghana and Nigeria. These two countries' economies have undergone several structure adjustment programs to bring them to a market economy following the many military dictatorships to create a central command economy.

The remaining sections of this paper are structured as follows. Section 2 provides the literature review and the general hypotheses. Section 3 Methodology, model, and the variables used in arriving at the study answer. Section 4 presents the study's findings and the main empirical results, and Section 5 concludes.

\section{LITERATURE REVIEW}

\section{A. Capital Structure}

There are two types of capital in a business - Debt and Equity. Each debt type has its own merits and demerits. Bradley et al. ( 1984) referred to the capital structure as one of the most critical issues for business. That is because both the financial risk of the business and the cost of capital are affected by the capital structure of a business. Capital structure refers to the contribution of debt, equity, and other securities that form the capital of a business (Titman et al., 2017). The combination of debt and equity is essential in minimizing the cost of capital to the business. The components of capital structure include both short-term and long-term debts and equity, and it is also referred to as the financial structure of a business (Jaffe and Randolph Westerfield, 2004).

Capital structure is important because it can increase the value of a business, maximize shareholders' wealth, and reduce the cost of capital to its lowest limit (Stiglitz, 1988). A well-planned capital structure prevents the company from the risk of insolvency as the business would not take on debt beyond its debt capacity. Also, a good plan ensures that the business can take advantage of wealth creation opportunities in the market. According to Kumar et al. (2017), the choice of capital structure is based on several factors, including firmspecific factors, industry-specific factors, and countryspecific factors.
Firm profitability shows the efficiency of management in converting the firm's resources to profit (Muya and Gathogo, 2016). The trade-off theory suggests that profitability is positively related to leverage (Awan and Amin, 2014). That is because profitable businesses can take on more debts. The pecking order theory predicts a negative relationship between profitability and capital structure (Eriotis et al., 2007). Afza and Hussain (2011) found an inverse relationship between profitability and capital structure in Pakistan.

Size is empirically proven to influence capital structure. As Al Ani and Al Amri (2015) argued, large firms can diversify their business with stable earnings, allowing them to take on more debts than smaller businesses. Titman and Wessels (1988) argued that large firms are more experienced and reputable and have a low risk of bankruptcy. That allows them to take on more debts. Larger firms also have easier access to the market (Kareem, 2019). Larger firms can issue debt security at a lower cost than smaller firms. Eriotis et al. (2007) and Opoku-Asante (2021) found a positive relationship between leverage and firm size. The trade-off theory dictates a positive relationship between leverage and firm size. On the contrary, the pecking order theory predicts an inverse relationship between capital structure and financial distress(Awan and Amin, 2014). Large firms have more diverse income sources and undertake expansion projects (Al Ani and Al Amri, 2015).

Asset Tangibility plays a critical role in the determination of capital structure. The pecking order and trade-off theories predict a positive relationship between asset tangibility and debt-to-equity ratios (Guizani and Ajmi, 2021). As asset tangibility provides collateral value, it is easy for firms with higher tangible assets to have easy access to debt than firms with lower value assets. The positive relationship between assets tangibility and debt-to-equity ratio have been proven empirically in the works of Handoo and Sharma (2014), Karadeniz et al. (2009), Nhung et al. (2017), and Nnadi (2017).

Taxes influence the capital structure of the business. Awan and Amin (2014) found a significant positive relationship between debt ratio and debt. The tax shield, which reduces the marginal interest rate on loans, increases the incentive for firms to acquire more debts. As such, any upwards adjustment in tax rate encourages firms to increase loans to reduce their tax payments as interest on loans is tax-deductible. However, according to Zurigat (2009), firms with other tax deductibles, such as investment credits, may not experience a relationship between leverage and tax rate.

Huang (2006) found a negative relationship between growth opportunity and leverage. Growth opportunities come from intangible assets of the business (Zurigat, 2009). The trade-off theory dictates an inverse relationship between growth opportunities and capital structure, while the pecking order theory predicts a positive relationship.

Marimuthu and Hamzah (2020) summarize the directional relationship between leverage and firm-specific factors per the dictates of both the pecking order and trade-off theory.

\section{B. Capital Structure Theory}

The irrelevance arguments of capital structure proposed by Modigliani and Miller (1958) kicked off discussions on modern finance theory. There was no broadly acknowledged 
capital structure theory before their study. In their fundamental paper, Modigliani and Miller (1958) suggested that a company's capital structure is unimportant under ideal market conditions. This theory provides for the capital structure that does not influence a business's financial performance with perfect market conditions. However, financial performance is influenced by the mix of business risk and earning opportunities. This theory provides that a market value of a business is not affected by how the business activities are financed. The MM theory provides for two prepositions. The first proposition provides classical arbitrage-based irrelevance (Titman et al., 2017). Under this proposition value of a firm's stock results from the total value of cash flow that the business can generate. MM Proposition II provides that both capital structure and dividend policies are irrelevant in determining the value of a business (Titman et al., 2017). This theory provided that all firms in a market will have a similar value irrespective of financing. Per this theory, the critical thing is how the business resources are invested and managed, not how the resources are financed.

The assumption of a perfect market has made it difficult to test empirically. Luigi and Sorin (2009) argued that testing the MM theorem is difficult. Several researchers have concluded that the MM theorem fails in many situations as there is no perfect market. As firms do not have the same business environment, it is erroneous to assume that all firms belong to the same risk class (Stiglitz, 1988). Also, individuals and businesses cannot borrow at the same terms. According to Frank and Goyal (2003), the MM theorem is an abstract mathematical model developed without empirical data and analysis. The Modigliani and Miller theorem is crucial to this study since it establishes a neutral and impartial link between the financial performance of the business and how the business is financed.

The pecking order theory gives a clear hierarchical means of funding business operations without aiming at a predefined debt to equity ratio. It provides that businesses seek to choose the lowest cost source of funding in their capital structure decisions. As a result, firms prefer to finance capital projects with internal funds when available. When internal finances are insufficient or unavailable, firms then obtain finances from external sources with loans before issuing new equity. Myers and Majluf (1984) argued that the differences in the cost of funds for the various fund sources arise because of information asymmetry between investors and businesses. Given the hierarchy of financing per the theory, a situation where the business cannot follow this hierarchy does not invalidate the theory (Shen, 2014). It only indicates the limitation preventing the business from reaching its desired capital structure. According to Le and Phan (2017), the pecking order theory may not be empirically proven in an underdeveloped market due to the lack of development of the debt market, not because of the invalidity of the theory.

The trade-off theory was developed, building from the works of Modigliani and Miller (1958). First introduced by Kraus and Litzenberger (1973) and formalized by Jensen and Meckling (1976), the trade-off theory provides a predetermined debt ratio at which the cost and benefits of debts are optimized. The theory calls for an optimum financing mix of debt and equity that maximizes the benefit and minimizes the cost of debt. If the firm wishes to maximize shareholder value, this theory should attain or maintain the optimal capital structure (Brounen et al., 2006). The tax shield from interest on debt increases the business's cash flow through reduced taxes, increasing the value of the business. The trade-off theory suggests that as the level of firm debts increases, the financial risk level of the firms also increases, which makes equity holders unwilling to provide further funds or request higher dividend payments as compensation for the higher risk (Myers, 1977). Several variations of the trade-off theory have been proposed in the literature. The dynamic trade-off theory considers the adjustment cost to the optimal funding mix. According to Mauer and Triantis (1994), the cost of adjusting to the optimal debt ratio places boundaries on the optimal leverage ratio. Brennan and Schwartz (1984) adjusted the trade-off theory making provision for investment policy. Firms should determine the portion of debt capital to be held in cash and the portion to be invested.

\section{Capital Structure and Financial Performance}

An empirical study by Abdullah and Tursoy (2021) on nonfinancial firms in Germany over 25 years found a significant positive relationship between capital structure and financial performance. They found that the lower cost of issuing debt and tax shield from the interest of the dept was the main course of the positive relationship. Hung et al. (2002) also found a positive relationship between capital structure and the financial performance of firms in Hong Kong. In another study, Khaliq et al. (2014) found that leverage significantly influences the financial performance of publicly listed firms in Malesia. Mujahid and Akhtar (2014) studied textile firms in Pakistan and found a positive relationship between capital structure and financial performance. Several other studies have found leverage as a significant contributor to the financial performance of firms (Abu-Rub, 2012; Kodongo et al., 2015; Nerlove, 1968). Banks look at the financial performance of firms that are demanding more loans before advancing further debt funding. Firms demanding further loans must demonstrate higher financial performance to justify the need for more debt funding (Margaritis and Psillaki, 2010). Several other studies have found a positive relationship between capital structure and financial performance (Berger and Di Patti, 2006; Dessí and Robertson, 2003).

On the contrary, some other empirical studies have resulted in an inverse relationship between capital structure and financial performance. Abor (2005) used various means of measuring capital structure and found that capital structure negatively influenced the financial performance of firms. Vithessonthi and Tongurai (2015) also found a negative relationship between leverage and the financial performance of firms in Thailand. Rouf and Abdur (2015), using regression analysis, also found an inverse relationship between capital structure and financial performance of nonfinancial firms listed on the Dhaka stock exchange. According to Soumadi and Hayajneh (2012), more debt leads to higher interest payment depriving the firms of cash resources and restricting assets as they are used collateral. Several other studies have found an inverse relationship between capital structure and financial performance (Abor, 2007; de Jong et al., 2008; Gleason et al., 2000; Mateev et 


\section{al., 2013; Simerly and Li, 2000).}

Empirical studies on the matter performed on firms in Nigeria and Ghana separately have also been inconclusive. Oke et al. (2019), in a study of the effect of debt on capital structure performance for conglomerate firms operating in Nigeria, found a significant positive relationship between capital structure and financial performance. Akingunola et al. (2018), in a sample study of 21 listed non-financial firms, found inconsistent results when the measure of financial performance changed between return on equity (ROE) and Return on Assets (ROA). When the performance was measured as ROA, the study found a significant negative relationship between capital structure and financial performance. However, when performance was measured as ROE, the study found a positive relationship between shortterm debt to total capital and long-term debt to total capital and financial performance. Addae et al. (2013), in a study of both financial and non-financial firms listed on the Ghana stock exchange, found a negative relationship between shortterm debt ratio and financial performance and a positive relationship between long-term debt ratio and financial performance. They also found a negative relationship between the total debt ratio and financial performance. Abor (2007), in a study of the relationship between capital structure and financial performance of SMEs in Ghana and South Africa, discovered a negative relationship between long-term debt and total debt ratio to financial performance.

The empirical studies have found mixed results for the relationship between capital structure and financial performance. Weill (2008) found that the association between capital structure and financial distress varies from one country to another. He also concluded that institutional factors in the country influence the relationship between capital structure and financial performance. The literature on the relationship between capital structure and financial performance or firm value is still being debated as empirical results have been mixed and inconsistent. However, as Weill (2008) noted, the intuitional and country factors also influence the relationship between capital structure and the firms' performance. No study has examined the relationship between capital structure and firm performance for public firms operating in West Africa, considering the debt maturity and sectorial effects. We attempt to fill this void. This study adopts a sectorial specific analysis of the mixed results of the relationship between capital structure and financial performance. Also, by adopting the proportionate analyses of total leverage, long-term and short-term leverage, the effect of the timing of debt repayment on the financial performance for each sector is considered in the analysis. The object is to identify any discrepancy between the debt maturity on financial performance that managers, policymakers, and investors should be made aware of when making financing decisions. To the authors' knowledge, no other study on the relationship between capital structure and financial performance in Ghana and Nigeria has been conducted to include the relationship on an industrial base and debt maturity basis. This study contributes to existing literature and fulfills the research gap.

\section{METHODOLOGY}

This study aimed to identify the relationship between how businesses in Ghana and Nigeria are financed and the financial performance of these businesses. The study further analyzes this relationship for the various industries of the firms. The study used a quantitative correlational study design in answering the research hypotheses.

Q1. What is the relation between capital structure and financial performance of firms in West African companies?

Null Hypotheses (H01): There is no relation between the capital structure of companies operating in Ghana and Nigeria and financial performance.

Alternative Hypotheses (Ha1): There is a relation between the capital structure of companies operating in Ghana and Nigeria and financial performance.

Q2 What effect does debt maturity have on the relationship between capital structure and financial performance?

Null Hypotheses (H02): Debt maturity has no effect on the relations between the capital structure of companies operating in Ghana and Nigeria and financial performance.

Alternative Hypotheses (Ha2): Debt maturity has an effect on the relations between the capital structure of companies operating in Ghana and Nigeria and financial performance.

Q3. Does the Industry influence the relationship between capital structure practice and financial performance of firms in West Africa?

Null Hypotheses (H03): The relationship between the capital structure of companies operating in Ghana and Nigeria and financial performance is the same for all industries.

Alternative Hypotheses (Ha3): The relationship between the capital structure of companies operating in Ghana and Nigeria and financial performance is not the same for all industries.

The study population was all non-financial public firms in Ghana and Nigeria at the close of December 2019. Financial firms such as banks, investment firms, and insurance companies were excluded because they are heavily regulated regarding their capital requirements and structure. Conglomerate firms and firms that merged over the study period were also excluded from the population. The study population was 131 firms. A stratified sampling method was adopted with the various industries used as the strata. A total of 85 firms were sampled for the study. We obtained data from the published financial statements from 2014 to 2018. The study period of 5 years was appropriate in determining a stable variance of the variable of the study. The period was also essential in estimating a stable relationship of the study variables. The study excluded 2019 to 2020 to avoid the impact of economic lockdown because Covid-19 might have added the relationship between capital structure and financial performance. The collected data from the financial statements of the sampled firms were converted to the relevant ratios for the analysis using Microsoft Excel and later into SPSS for further analysis. A total of 425 firms years were analyzed in this study. The Pearson correlational method was adopted. That involved regressing capital structure represented by the total debt to equity ratio, long-term debt to equity ratio, and short-term debt to equity ratio to financial performance represented as the return on equity and return on assets.

We assumed the relationship between capital structure and 
financial performance. This relationship we expressed mathematically as:

$$
\text { Rit }=\beta 0+\beta 1 \mathrm{LEVit}+\varepsilon \text { it }
$$

where Rit is financial performance, LEV is the leverage, and cit is the error term. As we are interested in the effect of the timing of debt maturity on financial performance, we expressed the proportionate composition of debt ratio mathematically as:

$$
\mathrm{Rit}=\beta 0+\beta 1 \mathrm{LLEVit}+\beta 2 \mathrm{SLEVit}+\varepsilon i t
$$

where LLEV is defined as the long-term debt ratio and SLEV as the short-term debt ratio. Rit and cit remain the same as previously defined. The analytical tool adopted for the study was the ordinary least square in an attempt to answer the research question.

The capital structure of the sampled firms was determined using the total debt ratio, the long-term debt ratio, and the short-term debt ratio. We choose to disintegrate leverage into its proportionate parts to determine the impact of each part on the financial performance of firms in different industries. The proportionate debt analysis allows us to determine the amount that firms must pay to debt holders in relation to financial performance and the timing of the debt repayments to financial performance. The proportion of the various components of capital is claimed in the finance literature to have a different effect on the financial performance of firms. Lau et al. (2016) used the proportionate debt components to determine the relationship between capital structure and firm stock returns in Malaysia. In this study, the total debt ratio was measured as the business's total debt over the business's total capital.

$$
\begin{aligned}
& \text { Total Debt Ratio } \\
& =\frac{\text { short }- \text { term debt }+ \text { Long }- \text { term debt }}{\text { Total Capital }}
\end{aligned}
$$

Long-term debt ratio was measured as the long-term debt to total capital.

$$
\text { Long }- \text { Term Debt Ratio }=\frac{\text { Long }- \text { term debt }}{\text { Total Capital }}
$$

Short term debt ratio was measured as the short-term debt ratio to total capital.

$$
\text { Short }- \text { Term Debt Ratio }=\frac{\text { Short }- \text { term debt }}{\text { Total Capital }}
$$

As Lau et al. (2016) argued, debt maturity could have some implications for financial performance.

Return on Equity (ROE) and Return on Assets (ROA) was the measures of financial performance. ROA attempts to determine how much the firm earns from the use of its assets. ROA shows the amount of profit earned for each investment value in the firms' assets. We determined ROA as:

$$
R O A=\frac{\text { Net Income }}{\text { Total Assets }}
$$

ROE refers to a profitability measure that determines how well the business is utilizing the funds invested by equity holders of the business. ROE was obtained by dividing net income by shareholders' equity.

$$
R O E=\frac{\text { Net Income }}{\text { Shareholders Equity }}
$$

\section{Study Results}

To determine the relationship between financial performance, measured as ROE and debt structure, we regressed debt to maturity on ROE. The regression results suggested that this model was statistically insignificant in determining a relationship between capital structure and financial performance $([\mathrm{R}=0.004, \operatorname{Radj}=-0.03, \mathrm{~F}(2,422)=$ $0.56, \mathrm{p}=0.658]$. Neither short-term debt ratio, long-term debt ratio, nor Total debt ratio significantly influenced the ROE. That suggested that the timing of debt repayment did not affect the financial performance of firms. This finding is inconsistent with Abor (2005), who found a positive relationship between capital structure, represented as total debt ratio and short-term debt ratio and ROE of firms in Ghana. Ahmed and Teru (2020) also found a positive relationship between capital structure and ROE for deposittaking institutions in Nigeria. Pham (2020) found a positive relationship between the total debt ratio, long-term debt ratio, and ROE. The result is also contrary to Le and Phan (2017), who found a significant positive relationship between capitals structure and financial performance of firms in Vietnam.

\begin{tabular}{|c|c|c|c|c|c|}
\hline & B & $\beta$ & $\mathrm{t}$ & $\mathrm{p}$ & Partial r \\
\hline (Con) & 0.230 & & 0.755 & 0.451 & \\
\hline STDR & 0.013 & 0.003 & 0.060 & 0.952 & 0.003 \\
\hline LTDR & -0.476 & -0.058 & -1.046 & 0.296 & -0.051 \\
\hline TDR & 0.082 & 0.018 & 0.361 & 0.718 & 0.018 \\
\hline
\end{tabular}
Mwangi et al. (2014) found a negative relationship between the total debt ratio and ROE for firms in Kenya. The result is consistent with Anarfo (2015) and Phan (2019), who found no significant relationship between capital structure and financial performance. Table I provides a summary of the regression results.

TABLE I: RELATIONSHIP BETWEEN CAPITAL STRUCTURE AND ROE

When this relationship is evaluated sectoral, the health care, ICT, Industrial Goods, Natural Resources, Oil and Gas, and the Services industry exhibited a similar insignificant relationship between capital structure and financial performances. Similarly, debt maturity had no effect on the performance of firms in these industries. However, the Agricultural, Construction, and Consumer goods industries exhibited a significant relationship between capital structure and financial performance. The short-term debt ratio and long-term debt ratio did not significantly affect financial performance for these three industries. The total debt ratio significantly influenced financial performance in Agriculture, Construction, and Consumer goods industries. There was a significant negative relationship between the total debt ratio and financial performance for the Agricultural Industry. The construction and consumer goods industries resulted in a significant positive relationship between the total debt ratio and financial performance. Appendix A shows details of the 
relationship based on industrial analysis.

A country analysis of the relationship between capital structure and financial performance revealed no significant relationship between capital structure and financial performance (ROE) for firms in Ghana across all industries $(\mathrm{R}=0.29$, $\operatorname{Radj}=-0.04, \mathrm{~F}(2,67)=2.00, \mathrm{p}=0.12)$. Like Ghana, we did not find any significant relationship between capital structure and ROE for firms operating in Nigeria ( $R$ $=0.05, \operatorname{Radj}=-0.01, F(2,352)=0.00, p=0.81)$. These results are contrary to those of Abor (2005), Mustapha et al. (2020), and Ahmed and Teru (2020).

We also examined the relationship between capital structure and financial performance when profitability is measured as Return on Assets (ROA). The results suggested that there is a significant relationship between capital structure and financial performance for public firms operating in Ghana and Nigeria $([\mathrm{r}=0.27, \operatorname{Radj}=-0.07, \mathrm{f}(2,422)=$ $10.93, \mathrm{p}<0.00]$ ). However, debt maturity had no influence on the relationship between capital structure and financial performance. There was no significant relationship between short-term debt ratio and financial performance $(r=0.01, p$ $=0.79$ ). Similarly, there was no significant relationship between long-term debt ratio and financial performance $(r=$ $0.04, p=0.36)$. Total debt ratio had a significant negative relationship between with financial performance $(\beta=0.26, p$ $<0.00$ ). That suggests that as debt increases, there would be a reduction in the firm's profitability. Unlike the results of this study Bui (2017), Gill et al. (2011), and Gul and Cho (2019) found a significant positive relationship between short-term debt and ROA. The study results were consistent with Onaolapo and Kajola (2010) after finding a negative relationship between the total debt ratio and ROA for Nigerian firms from 2001 to 2007. Table II provides details of the relationship between capital structure and ROA.

TABLE II: RELATIONSHIP BETWEEN CAPITAL STRUCTURE AND PROFITABILITY (ROA)

\begin{tabular}{cccccc}
\hline & B & $\beta$ & $t$ & $p$ & Partial $r$ \\
\hline (Cons) & 118 & & 5.265 & 0.000 & \\
STDR & 0.004 & 0.015 & 0.271 & 0.786 & 0.013 \\
LTDR & -0.031 & -0.049 & -0.917 & 0.360 & 0.045 \\
TDR & -0.093 & -0.260 & -5.529 & 0.000 & 0.26 \\
\hline
\end{tabular}

Sectorial analysis reveals that the relationship between capital structure and financial performance is significant for firms operating in the Agriculture, Construction, Natural Resources, and service industries when financial performance is measured as ROA. In the Agricultural sector, the total debt ratio was the only factor that was significantly inversely related to financial performance $(\beta=-0.594, p<0.00)$. We observed a similar pattern where only the total debt ratio is inversely related to financial performance in the Natural Resource industry $(\beta=-0.15, p<0.00)$. and the Services industry $(\beta=-0.10, p<0.00)$. That suggested that the timing of debt repayment did not influence the financial performance of firms in the Agricultural, Natural Resources, and Services sectors in Ghana and Nigeria.

In the construction industry, the timing of debt repayment had a significant influence on firms' financial performance. Short-term debt ratio, long-term debt ratio, and total debt ratio all significantly influence the financial performance of firms in the construction sector. While short-term debt $(\beta=7.59 \mathrm{p}$
$<0.00)$ and Long-term debt $(\beta=7.69, \mathrm{p}<0.00)$ positively related to financial performance, total debt $(\beta=-0.59, \mathrm{p}<$ $0.00)$ inversely related to financial performance. There was no relationship between capital structure and financial performance for all the other industries. Appendix B details the sectorial analysis when financial performance is measured as ROA.

A country analysis of the relationship between capital structure and ROA suggest a significant relationship between capital structure of and financial performance for firms in Ghana $(\mathrm{R}=0.54, \operatorname{Radj}=0.26, \mathrm{~F}(2,67)=9.24, \mathrm{p}<0.00)$. The total debt ratio was the only capital structure element that was inversely related to ROA $(\beta=-0.59, \mathrm{p}<0.00)$. At means that acquiring more debts leads to a decline in financial performance. It also indicated that for firms in Ghana, the timing of debt repayment does not influence the financial performance of firms. For firms in Nigeria, we found significant relationship between capital structure and ROA (R $=0.24, \operatorname{Radj}=-0.05, F(2,352)=6.97, \mathrm{p}<0.00)$. Similar to what pertains to Ghana, total debt was the capital structure element that inversely related to financial performance $(\beta=$ $0.08, p<0.00$ ). That suggests that debts lead to a decline in the financial performance in both Ghana and Nigeria.

\section{CONCLUSION}

Following the empirical analysis, we reject all the Null hypotheses and accept all the Alternate hypotheses.

1. The study revealed a significant relationship between capital structure and financial performance. This relationship is largely dependent on the factor chosen as a measure of capital structure, the Industry of the firms involved, and the factors of financial performance, confirming similar findings by (Akingunola et al., 2018).

2. This study's results suggested no significant relationship between capital structure and ROE. Sectorial analysis revealed that only the Agricultural negatively related to $\mathrm{ROE}$ while the Construction and Consumer goods firms positively related to ROE. All other industries did not exhibit any relationship between ROE and Capital structure.

3 . The result suggested a significant negative relationship between total debt and ROA.

4. Debt maturity did not affect the relationship between capital structure and financial performance except in the construction industry.

These findings contribute to the depth of knowledge on the effect of debt maturity on the financial performance of firms in the West African region. It also contributes to knowledge on the relationship between capital structure and financial performance. These findings have practical implications for financial decision-making. As the time to debt maturity did not significantly influence financial performance, it suggests that managers of firms can acquire any time of debt readily available. In the West African market, short-term debts are readily available to managers, and they can explore shortterm debts to their advantage as debt maturity does not influence the firm's financial performance in the region. However, in taking such financial decisions, managers must consider their sector of operation as the sectorial analysis reveal an effect of debt maturity on the relationship between 
capital structure and financial performance in the construction industry.

This study looked at the relationship that existed before the impact of the covid pandemic. Future studies can look at the effect of the covid pandemic on the relationship between capital structure and financial performance. As covid has become the new normal, other empirical studies that examine the covid impact on the relationship between capital structure and financial performance can assist managers in making meaningful decisions. So, the study is limited to public firms operating on the Ghana stock exchange and the Nigeria Stock exchange. Further studies should examine if this relationship can be established in other jurisdictions, including developed and developing economies. The choice of financial performance was limited to Return on Assets and Return on
Equity; future studies can examine the relationship using other financial performance measures such as the net profit margin, operating cash flow, Earnings Before Interest, Taxes, Depreciation, and Amortization (EBITDA) and other measures of profitability. We excluded the financial sectors firms and conglomerate firms to examine the sectorial effect of the relationship. Financial institutions were excluded because they are highly regulated regarding their capital requirement. Future studies can ascertain the relationship between capital structure and financial performance of financial firms, considering the effect of the sectorial regulations.

\section{Appendix A}

\section{APPENDIX}

\begin{tabular}{|c|c|c|c|c|c|c|c|c|c|}
\hline \\
\hline & Agriculture & Construction & $\begin{array}{c}\text { Consumer } \\
\text { Goods }\end{array}$ & Health Care & ICT & $\begin{array}{c}\text { Industrial } \\
\text { Goods }\end{array}$ & $\begin{array}{c}\text { Natural } \\
\text { Resources }\end{array}$ & $\begin{array}{c}\text { Oil and } \\
\text { Gas }\end{array}$ & Services \\
\hline & $\begin{array}{c}\text { Beta } \\
\text { (p value) }\end{array}$ & $\begin{array}{c}\text { Beta } \\
\text { (p value) }\end{array}$ & $\begin{array}{c}\text { Beta } \\
\text { (p value) }\end{array}$ & $\begin{array}{c}\text { Beta } \\
\text { (p value) }\end{array}$ & $\begin{array}{c}\text { Beta } \\
\text { (p value) }\end{array}$ & $\begin{array}{c}\text { Beta } \\
\text { (p value) }\end{array}$ & $\begin{array}{c}\text { Beta } \\
\text { (p value) }\end{array}$ & $\begin{array}{c}\text { Beta } \\
\text { (p value) }\end{array}$ & $\begin{array}{c}\text { Beta } \\
\text { (p value) }\end{array}$ \\
\hline \multicolumn{10}{|l|}{ Variables } \\
\hline \multirow[t]{2}{*}{ Constant } & 0.362 & -7.487 & -0.002 & -0.094 & 0.237 & -1.208 & 0.131 & 0.062 & 0.015 \\
\hline & $(0.000)$ & $(0.002)$ & $(0.990)$ & $(0.961)$ & $(0.061)$ & $(0.424)$ & $(0.000)$ & $(0.151)$ & $(0.921)$ \\
\hline \multirow[t]{2}{*}{ STD } & - & 7.589 & 0.188 & 0.139 & -0.184 & 1.447 & - & 0.011 & 0.109 \\
\hline & - & $(0.002)$ & $(0.103)$ & $(0.943)$ & $(0.153)$ & (0.339) & - & $(0.418)$ & $(0.481)$ \\
\hline \multirow[t]{2}{*}{ LTD } & 0.005 & 7.693 & -0.054 & 0.221 & -0.113 & 1.240 & -0.046 & -0.153 & 0.078 \\
\hline & $(0.932)$ & $(0.001)$ & $(0.654)$ & $(0.911)$ & $(0.102)$ & $(0.410)$ & $(0.121)$ & $(0.042)$ & $(0.616)$ \\
\hline \multirow[t]{2}{*}{ TDR } & -0.594 & -.174 & -0.062 & -0.086 & - & -0.164 & -0.147 & 0.027 & -0.101 \\
\hline & $(0.000)$ & $(0.010)$ & $(0.211)$ & $(0.236)$ & - & $(0.60)$ & $(0.000)$ & $(0.585)$ & $(0.000)$ \\
\hline \multicolumn{10}{|l|}{ Statistics } \\
\hline Regression & 0.794 & 0.715 & 0.422 & 0.211 & 0.326 & 0.321 & 0.857 & 0.319 & 0.286 \\
\hline R Squared & 0.630 & 0.511 & 0.178 & 0.045 & 0.106 & 0.103 & 0.735 & 0.102 & 0.082 \\
\hline \multirow{2}{*}{$\begin{array}{c}\text { Adjusted R } \\
\text { Squared } \\
f \text { statistic }\end{array}$} & 0.596 & 0.455 & 0.154 & 0.025 & 0.058 & 0.059 & 0.711 & 0.049 & 0.074 \\
\hline & 0.000 & 0.000 & 0.000 & 0.594 & 0.125 & 0.082 & 0.000 & 0.138 & 0.000 \\
\hline
\end{tabular}

Appendix B

Industrial ANALYSis of RELATIONSHIP BETWEEN CAPITAL STRUCTURE AND PROFITABILITy (ROA)

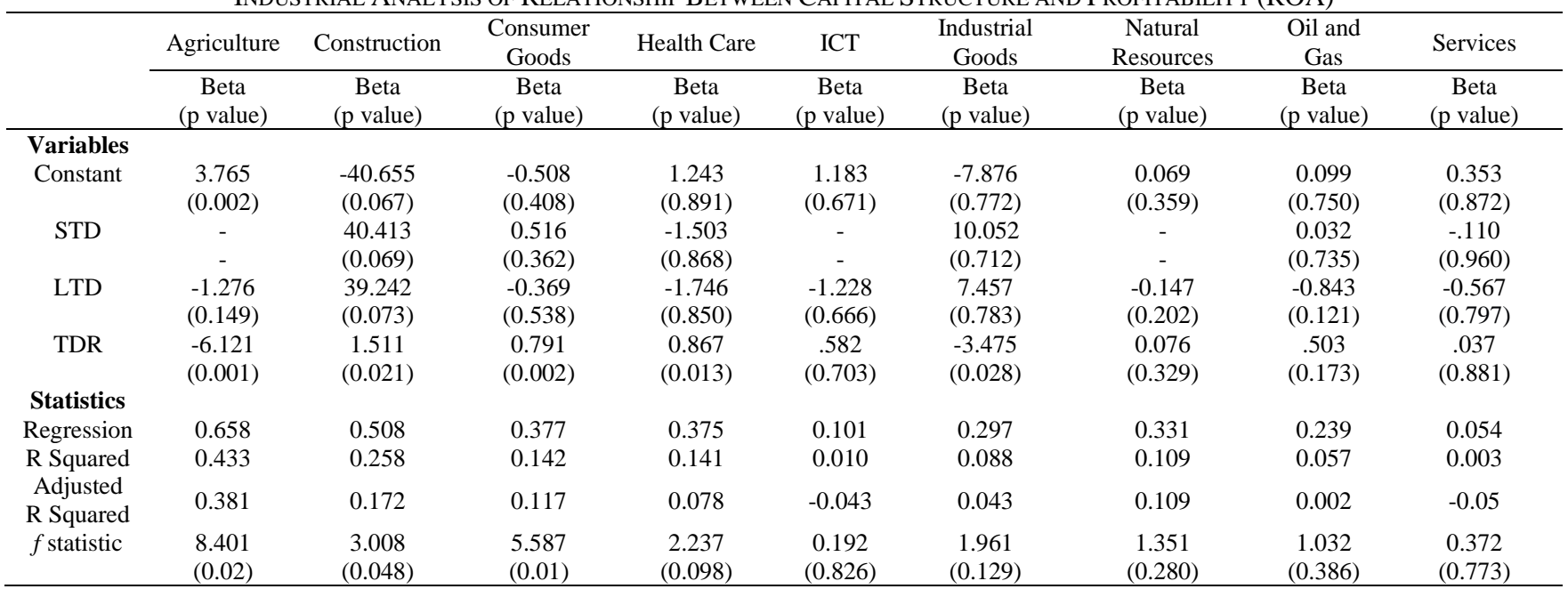

\section{REFERENCES}

Abdullah, H., \& Tursoy, T. (2021). Capital structure and firm performance: evidence of Germany under IFRS adoption. Review of Managerial Science, 15(2), 379-398. https://doi.org/10.1007/s11846-019-00344-5.

Abor, J. (2005). The effect of capital structure on profitability: an empirical analysis of listed firms in Ghana. The journal of risk finance, 6(5), 438445. https://doi.org/10.1108/15265940510633505.

Abor, J. (2007). Debt policy and performance of SMEs: Evidence from Ghanaian and South African firms. The journal of risk finance, 8(4), 364-379. https://doi.org/10.1108/15265940710777315.
Abu-Rub, N. (2012). Capital structure and firm performance: Evidence from Palestine stock exchange. Journal of Money, Investment and Banking, 23(1), 109-117.

Addae, A. A., Nyarko-Baasi, M., \& Hughes, D. (2013). The effects of capital structure on profitability of listed firms in Ghana. European Journal of Business and Management, 5(31), 215-229.

Afza, T., \& Hussain, A. (2011). Determinants of capital structure across selected manufacturing sectors of Pakistan. International Journal of Humanities and Social Science, 1(12), 254-262. https://lahore.comsats.edu.pk.

Ahmed, A., \& Teru, P. (2020). The impact of capital structure on financial 
performance of the listed deposit money banks: evidence from Nigeria. International Journal of Research in Finance and Management, 3(2), 13-18. https://doi.org/doi.org/10.33545/26175754.2020.v3.i2a.72.

Akingunola, R. O., Olawale, L. S., \& Olaniyan, J. D. (2018). Capital structure decision and firm performance: Evidence from non-financial firms in Nigeria. Acta Universitatis Danubius. Economica, 13(6).

Al Ani, M., \& Al Amri, M. (2015). The determinants of capital structure: an empirical study of Omani listed industrial companies. Business: Theory and Practice, 16(2), 159-167. https://doi.org/10.3846/btp.2015.471.

Anarfo, E. B. (2015). Capital-Structure-And-Bank-Performance---Evidence-From-Sub-Sahara-Africa. European Journal of Accounting Auditing and Fianace Research, 3(3), 1-20. www.eajournals.org.

Awan, A. G., \& Amin, M. S. (2014). Determinants of capital structure. European Journal of Accounting Auditing and Finance Research, 2(9), 22-41. https://www.eajournals.org.

Benmelech, E., \& Dvir, E. (2013). Does short-term debt increase vulnerability to crisis? Evidence from the East Asian financial crisis Journal of International Economics, 89(2), 485-494. https://doi.org/10.3386/w17468.

Berger, A. N., \& Di Patti, E. B. (2006). Capital structure and firm performance: A new approach to testing agency theory and an application to the banking industry. Journal of Banking \& Finance 30(4), 1065-1102. https://doi.org/10.2139/ssrn.361280.

Bradley, M., Jarrell, G. A., \& Kim, E. H. (1984). On the existence of an optimal capital structure: Theory and evidence. The journal offinance 39(3), 857-878. https://doi.org/10.2307/2327950.

Brennan, M. J., \& Schwartz, E. S. (1984). Optimal financial policy and firm valuation. The journal offinance, 39(3), 593-607. https://doi.org/10.2307/2327917.

Brigham, E. F., \& Gapenski, L. C. (1996). Intermediate finance management. J. Harbour Drive, The Dryden Press.

Brounen, D., De Jong, A., \& Koedijk, K. (2006). Capital structure policies in Europe: Survey evidence. Journal of Banking \& Finance, 30(5), $1409-1442$.

Bui, D. T. (2017). Impact of capital structure and working capital on the financial performance of small and medium-sized enterprises. Finance Magazine. http://tapchitaichinh.vn.

de Jong, A., Kabir, R., \& Nguyen, T. T. (2008). Capital structure around the world: The roles of firm- and country-specific determinants. Journal of

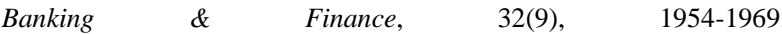
https://doi.org/10.1016/j.jbankfin.2007.12.034.

Dessí, R., \& Robertson, D. (2003). Debt, incentives and performance: Evidence from UK panel data. The Economic Journal, 113(490), $903-$ 919.

Eriotis, N., Vasiliou, D., \& Ventoura-Neokosmidi, Z. (2007). How firm characteristics affect capital structure: an empirical study. Managerial Finance. https://doi.org/10.1108/03074350710739605.

Frank, M. Z., \& Goyal, V. K. (2003). Testing the pecking order theory of capital structure. Journal of financial economics, 67(2), 217-248. https://doi.org/10.2139/ssrn.243138.

Gallegos Mardones, J., \& Ruiz Cuneo, G. (2020). Capital structure and performance in Latin American companies. Economic researchEkonomska istraživanja, 33(1), 2171-2188.

Gill, A., Biger, N., \& Mathur, N. (2011). The effect of capital structure on profitability: Evidence from the United States. International journal of management, 28(4), 3.

Gleason, K. C., Mathur, L. K., \& Mathur, I. (2000). The interrelationship between culture, capital structure, and performance: evidence from European retailers. Journal of business research, 50(2), 185-191. https://doi.org/10.1016/s0148-2963(99)00031-4.

Guizani, M., \& Ajmi, A. N. (2021). The capital structure decision of Islamic and conventional banks: empirical evidence from Malaysia. AsiaPacific Journal of Business Administration https://doi.org/10.1108/apjba-06-2020-0218.

Gul, S., \& Cho, H.-R. (2019). Capital structure and default risk: Evidence from Korean stock market. The Journal of Asian Finance, Economics, and Business, 6(2), 15-24 https://doi.org/10.13106/jafeb.2019.vol6.no2.15.

Handoo, A., \& Sharma, K. (2014). A study on determinants of capital structure in India. IIMB Management review, 26(3), 170-182. https://doi.org/10.1016/j.iimb.2014.07.009.

Huang, G. (2006). The determinants of capital structure: Evidence from China. China economic review, 17(1), 14-36 https://doi.org/10.1016/j.chieco.2005.02.007.

Hung, C. Y., Albert, C. P. C., \& Eddie, H. C. M. (2002). Capital structure and profitability of the property and construction sectors in Hong Kong.
Journal of Property Investment \& Finance. https://doi.org/10.1108/14635780210446469.

Jaffe, J., \& Randolph Westerfield, R. (2004). Corporate finance. Tata McGraw-Hill Education.

Jensen, M. C., \& Meckling, W. H. (1976). Theory of the firm: Managerial behavior, agency costs and ownership structure. Journal of financial economics, 3(4), 305-360. https://doi.org/10.1016/0304405X(76) $90026-\mathrm{X}$

Karadeniz, E., Kandir, S. Y., Balcilar, M., \& Onal, Y. B. (2009) Determinants of capital structure: evidence from Turkish lodging companies. International Journal of Contemporary Hospitality Management. https://doi.org/10.1108/09596110910967827.

Kareem, J. (2019). Effect of capital structure on the performance of quoted manufacturing firms in Sub-Saharan Africa Kwara State University (Nigeria)]

Khaliq, A., Altarturi, B. H. M., Thaker, H. M. T., Harun, M. Y., \& Nahar, N. (2014). Identifying Financial distress firms: a case study ofMMalaysia'sgovernment linked companies (GLC). International Journal of Economics, Finance and Management, 3(3). http://www.ejournalofbusiness.org.

Kodongo, O., Mokoaleli-Mokoteli, T., \& Maina, L. N. (2015). Capital structure, profitability and firm value: panel evidence of listed firms in Kenya. African Finance Journal, 17(1), 1-20. https://doi.org/10.2139/ssrn.2465422.

Kraus, A., \& Litzenberger, R. H. (1973). A state-preference model of optimal financial leverage. The journal offinance, 28(4), 911-922. https://doi.org/10.1111/j.1540-6261.1973.tb01415.x.

Kumar, S., Colombage, S., \& Rao, P. (2017). Research on capital structure determinants: a review and future directions. International Journal of Managerial Finance, 13(2), 106-132. https://doi.org/10.1108/ijmf-092014-0135.

Lau, W.-T., Law, S.-H., \& Nassir, A. M. (2016). DEBT MATURITY AND STOCK RETURNS: AN INTER-SECTORAL COMPARISON OF MALAYSIAN FIRMS. Asian Academy of Management Journal of Accounting \& Finance, 12(2). https://doi.org/10.21315/aamjaf2016.12.2.3

Le, T. P. V., \& Phan, T. B. N. (2017). Capital structure and firm performance: Empirical evidence from a small transition country. Research in international business and finance, 42, 710-726.

Luigi, P., \& Sorin, V. (2009). A review of the capital structure theories. Annals of Faculty of Economics, 3(1), 315-320. http://steconomiceuoradea.ro.

Margaritis, D., \& Psillaki, M. (2010). Capital structure, equity ownership and firm performance. Journal of Banking \& Finance, 34(3), 621-632. https://doi.org/10.1016/j.jbankfin.2009.08.023.

Marimuthu, M., \& Hamzah, H. H. (2020). Determinants of long-term financing decisions: an empirical investigation on the oil and gas firms in Malaysia. Platform: A Journal of Management and Humanities, 3(1), 59-70. http://myjms.mohe.gov.

Mateev, M., Poutziouris, P., \& Ivanov, K. (2013). On the determinants of SME capital structure in Central and Eastern Europe: A dynamic panel analysis. Research in international business and finance, 27(1), 28-51.

Mauer, D. C., \& Triantis, A. J. (1994). Interactions of corporate financing and investment decisions: A dynamic framework. The journal offinance, 49(4), 1253-1277.

Modigliani, F., \& Miller, M. H. (1958). The cost of capital, corporation finance and the theory of investment. The American economic review, 48(3), 261-297. https://www.jstor.org.

Mujahid, M., \& Akhtar, K. (2014). Impact of capital structure on firms financial performance and shareholders wealth: Textile sector of Pakistan. International Journal of Learning and Development, 4(2), 27-33. https://doi.org/10.5296/ijld.v4i2.5511.

Mustapha, A., Adio, B. A., \& Abdulazeez, T. (2020). Capital Structure and Financial Health: Evidence from Deposit Money Banks in Nigeria. International Journal of Technology and Management, 5(1), 1-11.

Muya, T., \& Gathogo, G. (2016). Effect of working capital management on the profitability of manufacturing firms in NAKURU town, KENYA International Journal of Economics, Commerce and Management, 4(4), 1082-1105. http://ijecm.co.uk.

Mwangi, L. W., Makau, M. S., \& Kosimbei, G. (2014). Relationship between capital structure and performance of non-financial companies listed in the Nairobi Securities Exchange, Kenya. Global Journal of Contemporary Research in Accounting, Auditing and Business Ethics, 1(2), 72-90.

Myers, S. C. (1977). Determinants of corporate borrowing. Journal of financial economics, 5(2), 147-175. https://doi.org/10.1016/0304- 


\section{5x(77)90015-0.}

Myers, S. C., \& Majluf, N. S. (1984). Corporate financing and investment decisions when firms have information that investors do not have. Journal of financial economics, 13(2), 187-221. https://doi.org/10.3386/w1396.

Nerlove, M. (1968). Factors affecting differences among rates of return on investments in individual common stocks. The Review of Economics and Statistics, 312-331. https://doi.org/10.2307/1937926.

Nhung, N. T. P., Lien, N. P., \& Hang, D. T. T. (2017). Analyze the determinants of capital structure for Vietnamese real estate listed companies. International Journal of Economics and Financial Issues, 7(4), 270-282.

Nnadi, M. (2017). Accounting Factors Affecting the Capital Structure in the Asian Economic Community. International Journal of Accounting Research, 05. https://doi.org/10.4172/2472-114X.1000139.

Oke, L. A., Saheed, D. O., \& Quadri, Y. O. (2019). An empirical analysis of corporate capital structure and financial performance of listed conglomerates in Nigeria. Copernican Journal of Finance \& Accounting, 8(3), 95-114. https://doi.org/10.12775/CJFA.2019.014.

Onaolapo, A. A., \& Kajola, S. O. (2010). Capital structure and firm performance: evidence from Nigeria. European Journal of Economics, Finance and Administrative Sciences, 25(1), 70-82.

Opoku-Asante, K. (2021). The Relationship Between Capital Structure Practices and Financial Distress in West Africa. Walden Dissertations and Doctoral Studies. 9988. https://scholarworks.waldenu.edu/dissertations/9988/.

Pham, C. D. (2020). The effect of capital structure on financial performance of Vietnamese listing pharmaceutical enterprises. The Journal of Asian Finance, Economics, and Business, 7(9), 329-340.

Phan, T. T. A. (2019). Does organizational innovation always lead to better performance? A study of firms in Vietnam. Journal of Economics and Development, 21(1), 71-82. https://doi.org/10.1108/JED-06-20190006.

Rouf, D., \& Abdur, M. (2015). Capital structure and firm performance of listed non-financial companies in Bangladesh. The International Journal of Applied Economics and Finance, 9(1), 25-32. https://doi.org/10.3923/ijaef.2015.25.32.

Shen, C. H.-h. (2014). Pecking order, access to public debt market, and information asymmetry. International Review of Economics \& Finance, 29, 291-306. https://doi.org/10.1016/j.iref.2013.06.002.

Simerly, R. L., \& Li, M. (2000). Environmental dynamism, capital structure and performance: a theoretical integration and an empirical test. Strategic management journal, 21(1), 31-49.

Soumadi, M. M., \& Hayajneh, O. S. (2012). Capital structure and corporate performance empirical study on the public Jordanian shareholdings firms listed in the Amman stock market. European Scientific Journal, $8(22)$.

Stiglitz, J. E. (1988). Economic organization, information, and development. Handbook of development economics, 1, 93-160. https://doi.org/10.1016/S1573-4471(88)01008-3.

Titman, S., Martin, J. D., Berk, J. B., \& DeMarzo, P. M. (2017). Intermediate Corporate Finance FINC6001. Pearson Education.

Titman, S., \& Wessels, R. (1988). The determinants of capital structure choice. The journal offinance, 43(1), 1-19. https://doi.org/10.2307/2328319.

Vithessonthi, C., \& Tongurai, J. (2015). The effect of firm size on the leverage-performance relationship during the financial crisis of 2007 2009. Journal of multinational financial management, 29, 1-29. https://doi.org/10.1016/j.mulfin.2014.11.001.

Weill, L. (2008). Leverage and corporate performance: does institutional environment matter? Small Business Economics, 30(3), 251-265. https://doi.org/10.1007/s11187-006-9045-7.

Zurigat, Z. (2009). Pecking order theory, trade-off theory and determinants of capital structure: empirical evidence from Jordan Heriot-Watt University]. 